\title{
KRITERIA AZAS PERADILAN YANG BAIK
}

\author{
NAMA : MUHAMAD FIQHAN SALIM \\ EMAIL : muhamadfiqhan07@gmail.com \\ NO BP : $\quad 1910003600011$
}

UNIVERSITAS EKA SAKTI

I. PENDAHULUAN

\subsection{Latar Belakang}

Dalam sistem ketatanegaraan Republik Indonesia terdapat tiga pilar kekuasaan negara, yaitu Kekuasaan Eksekutif, Legislatif dan Yudikatif. Berkaitan dengan kekuasaan Yudikatif (kehakiman) dalam pasala 24 UUD 1945 (perubahan) jo UU No 4 tahun 2004, ditegaskan bahwa kekuasaan kehakiman dilaksanakan oleh semua Mahkamah Agung dan badan-badan peradilan yang berada di bawahnya dalam lingkungan peradilan umum, lingkungan peradilan tata usaha negara dan sebuah Mahkamah Konstitusi.

Peradilan Tata Usaha Negara (PERATUN) sebagai lingkungan peradilan yang terakhir di bentuk, yang di tandai dengan disahkannya UU No 5 tahun 1986 pada tanggal 29 Desember 1986, dalam konsideran “ menimbang” UU tersebut disebutkan bahwa salah satu tujuan dibentuknya Peradilan Tata Usaha Negara (PERATUN) adalah untuk mewujudkan tata kehidupan negara dan bangsa sejahtera, aman, tentram 
serta tertib menjamin kedudukan masyarakat dalam hukum dan menjamin terpeliharanya hubungan yang serasi, seimbang serta selaras antara aparatur dibidang tata usaha negara dengan para masyarakat. Dengan demikian lahirnya PERATUN juga menjadi bukti bahwa Indonesia adalah ngara hukum yang menjunjung tinggi nilai-nilai keadilan kepastian hukum dan Hak Asasi Indonesia (HAM).

Dasar peradilan dalam UUD 1945 dapat ditemukan dalam pasal 24 yang menyebutkan: (1) Kekuasaan kehakiman dilakukan oleh sebuah Mahkamah Agung dan lain-lain badan kehakiman menurut undang-undang. (2) Susunan dan kekuasaan badan-badan kehakiman itu diatur dengan undang-undang.

Sebagai pelaksanaan Pasal 24 UUD 1945, dikeluarkanlah Undang-undang Nomor 14 Tahun Tahun 1970 tentang Ketentuan Pokok Kekuasaan Kehakiman. Dalam Pasal 10 ayat (1) disebutkan bahwa kekuasaan kehakiman dilakukan oleh pengadilan dalam lingkungan:

a. Peradilan Umum;

b. Peradilan Agama;

c. Peradilan Militer;

d. Peradilan Tata Usaha Negara.

Dengan demikian penyelenggaraan peradilan tata usaha negara di Indonesia merupakan suatu kehendak konstitusi dalam rangka memberikan perlindungan hukum terhadap rakyat secara maksimal.

Indonesia sebagai negara hukum tengah berusaha meningkatkan kesejahteraan bagi seluruh warganya dalam segala bidang. Kesejahteraan itu hanya dapat dicapai 
dengan melakukan aktivitas-aktivitas pembangunan di segala bidang. Dalam melaksanakan pembangunan yang multi kompleks sifatnya tidak dapat dipungkiri bahwa aparatur pemerintah memainkan peranan yang sangat besar. Konsekuensi negatif atas peran pemerintah tersebut adalah munculnya sejumlah penyimpanganpenyimpangan seperti korupsi, penyalahgunaan kewenangan, pelampauan batas kekuasaan, sewenang-wenang, pemborosan dan sebagainya. Penyimpanganpenyimpangan yang dilakukan oleh aparat pemerintahan itu tidak mungkin dibiarkan begitu saja. Disamping itu, juga diperlukan sarana hukum untuk memberikan perlindungan hukum bagi rakyat. Dengan diberlakukannya Undang-undang Nomor 5 Tahun 1986 jo UU No. 9 Tahun 2004 tentang Peradilan Tata Usaha Negara yang berdasarkan Pasal 144 dapat disebut Undang-undang Peradilan Administrasi Negara, maka dewasa ini perlindungan hukum terhadap warga masyarakat atas perbuatan yang dilakukan oleh penguasa dapat dilakukan melalui 3 badan, yakni sebagai berikut:

a. Badan Tata Usaha Negara, dengan melalui upaya administratif.

b. Peradilan Tata Usaha Negara, berdasarkan Undang-undang Nomor 5 Tahun 1986 jo UU No. 9 Tahun 2004 tentang Peradilan Tara Usaha Negara (PTUN).

c. Peradilan Umum, melaui Pasal 1365 Kitab Undang-undang Hukum Perdata (KUHPerdata).

Melihat betapa pentingnya peran Peradilan Tata Usaha negara dalam menciptakan Negara Indonesia yang adil dan sejahtera, pemakalah tertarik untuk membahas lebih dalam mengenai Peradilan Tata Usaha Negara di Indonesia dengan membuat makalah yang berjudul: "Kriteria Asas Peradilan Yang Baik" 


\subsection{Rumusan Masalah}

1. Apa saja asas-asas hukum acara peradilan tata usaha negara ?

2. Apa saja Asas-asas Umum Pemerintahan Yang Baik ?

3. Apa saja Asas-asas Sistem Peradilan Pidana di Indonesia ? 


\section{PEMBAHASAN}

\subsection{Asas-asas Hukum Acara Peradilan Tata Usaha Negara}

Beberapa asas-asas hukum Peradilan Tata Usaha Negara yang menjadi karakteristik hukum acara Peradilan Tata Usaha Negara di antaranya sebagai berikut:

a. Asas praduga rechtmatig (vermoden van rechtmatigheid, praesumtio iustae causa) Asas praduga rechtmatig adalah gugatan tidak menunda atau menghalagi dilaksanakannya keputusan badan atau pejabat Tata Usaha Negara yang digugat (pasal 67 ayat (1) Undangundang no 5 tahun 1986;

b. Asas pembuktian bebas, Hakim yang menetapkan beban pembuktian. Hal ini berbeda dengan ketentuan 1865 BW. Asas ini dianut oleh pasal $101 \mathrm{UU}$ No 5 tahun 1986, hanya saja masih dibatasi ketentuan pasal 100.

c. Asas keaktifan Hakim (dominus Litis). Keaktifan kekuatan mengikat kedudukan para pihak karena tergugat adalah pejabat Tata Usaha Negara sedangkan penggugat adalah orang atau badan hukum perdata. Penerapan asas ini antara lain terdapat dalam ketentuan pasal 58,63 ayat (1) dan (2), pasal 80 dan pasal 85 .

d. Asas putusan Peradilan memiliki kekutan mengikat "erga omnes ". Sengketa TUN adalah sengketa hukum public. Dengan demikian putusan pengadilan berlaku bagi siapa saja, tidak hanya bagi para pihak yang 
bersangkutan. Dalam rangka ini kiranya ketentuan pasal 83 tentang intervensi bertentangan dengan asas erga omnes.

Selain empat asas tersebut diatas, Zairin Harahap menambahkan asas-asas yang lainnya, yang berlaku di peradilan lainnya. Berikut ini adalah asas-asas yang dikemukakan oleh Philipus M. Hadjon, sebagai berikut :

a. Asas para pihak harus di dengar (audit et alteram partem) para pihak mempunyai kedudukan yang sama.

b. Asas kesatuan beracara (dalam perkara yang sejenis)

c. Asas penyelenggaraan kekuasaan kehakiman yang bebas (pasal $24 \mathrm{UU}$ PTUN)

d. Asas siding terbuka untuk umum. Putusan mempunyai kekuatan hukum jika diucapkan dalam siding yang terbuka untuk umum (pasal 70 UU PTUN)

e. Asas pengadilan berjenjang (tingkat pertama PTUN) banding (PTUN) kasasi (MA) dimungkinkan pula PK (MA).

f. Asas pengadilan sebagai upaya terakhir. Sengketa sedapat mungkin diselesaikan melalui upaya administrasi (musyawarah mufakat), jika belum puas maka ditempuh upaya peradilan (pasal 48 UU PTUN)

g. Asas obyektivitas

h. Asas peradilan sederhana, cepat dan biaya ringan. 
Dengan berlandasan pada fungsi-fungsi pada asas-asas hukum tersebut, maka asas-asas hukum administrasi yang merupakan tempat bertumpunya norma-norma hukum administrasi, dapat dikatakan:

a. Asas-asas hukum administrasi akan memberikan arah dalam "posittiveringsarbeid" oleh pembentuka undang-undang (wetgever) maupun organ pemerintah (bestuursorganen).

b. Asas hukum administrasi akan memberikan pedoman bagi "administrative rechte" dalam melakukan interprestasi hukum guna menjamin ketetapan menentukan keputusan hakim.

c. Asas hukum administrasi memberikan tuntutan kepada warga masyarakat khususnya akademisi hukum administrasi melalui pemikiran-pemikiran dan pembuatan peraturan perundang-undang maupun hakim administrasi dalam melakukan koreksi terhadap peraturan perundang-undangan.

\subsection{Asas-asas Umum Pemerintahan Yang Baik}

Pemahaman terhadap asas-asas umum pemerintahan yang baik tidak dapat dilepas dari konteks kesejarahan, disamping dari segi gramatikalnya. Karena asas ini munccul dan proses sejarah sebagaimana tersebut di atas. Terlepas dari kenyataan bahwa kemudian asas-asas umum pemerintahan yang baik ini menjadi wacana yang dikaji dan berkembang dikalangan para sarjana sehingga melahirkan rumusan dan interpretasi yang beragam guna pemahaman awal kiranyan diperlukan pengertian dari konteks bahasa dan sejarah. Dengan berdasarkan kepada kedua konteks ini, asas-asas 
umum pemerintahan yang baik dapat dipahami sebagai asas-asas umum yang dijadikan sebagai dasar dan tata cara dalam penyelenggaraan pemerintahan yang baik, yang dengan cara dmikian penyelenggaraan pemerintahan ini menjadi baik, sopan, adil, dan terhormat, bebas dari kezaliman, pelanggaran peraturan, tindakan penyalahgunaan wewenang, dan tindakkan kewenang-wenangan.

Telah disebutkan bahwa asas-asas umum pemerintahan yang baik merupakan konsep erbuka dan lahir dari proses sejarah, oleh karena itu terdapat ruusan yang beragam mengenai asas-asas tersebut. Meskipun demikian dalam pembahsan ini tidak dibicarakan mengenai rumusan yang beragam itu, namun hanya memuat asas-asas umum pemerintahan yang baik yang telah dirumuskan oleh para penyusun Indonesia, khususnya Koentjoro Purbopranoto dan SF Marbun, telah merumuskan macammacam asas-asas umum pemerintahan yang baik sebagai berikut:

a. Asas kepastian hukum (principle of legal security);

b. Asas keseimbangan (principle of proportionality);

c. Asas kesamaan dalam mengambil keputusan (principle of equality);

d. Asas bertindak cermat (principle of carffulness);

e. Asas motivasi untuk setiap keputusan (principle of motivation);

f. Asas tidak mencampuradukan kewenangan (principle of competence);

g. Asas permainan yang layak (principle of fair play); 
h. Asas keadilan dan kewajaran (principle of reasonable or prohibition of arbitrariness);

i. Asas kepercayaan dan menanggapi pengharapan yang wajar (principle of meeting raised expectation);

j. Asas meniadakan akibat suatu keputusan yang batal (principle of undoing the concequences of an annulled decision);

k. Asas perlindungan atas pandangan atau cara hidup pribadi (principle of protecting the personal may of life);

1. Asas kebijaksanaan (sapientia);

m. Asas penyelenggaraan kepentingan umum (principle of public service)

\subsection{Asas-asas Sistem Peradilan Pidana di Indonesia}

Sebagaimana kita ketahui bersama, Sistem Peradilan Pidana (SPP) harus memiliki dasar (Ground Norm maupun Ground Program), tujuan utamanya untuk menciptakan tatanan sistem yang kondusif berjalan sesuai rel yang tetap sesuai dengan yang diinginkan. Adapun asas-asas yang menjadi landasan dalam mekanisme atau bekerjanya sistem peradilan pidana adalah sebagai berikut:

1. Asas Legalitas (Legality Principle)

Yaitu asas yang mendasari beroprasinya sistem peradilan pidana dan sebagai jaminan bahwa sistem peradilan pidana tidak akan bekerja tanpa landasan hukum 
tertulis. Asas ini berpangkal tolak pada kepentingan masyarakat yang dapat ditafsirkan sebagai kepentingan tata tertib hukum. Dengan asas ini sistem peradilan pidana hanya dapat menyentuh dan mengelindingkan suatu perkara jika terdapat aturan-aturan hukum yang telah dibuat sebelumnya dan telah dilanggar.

\section{Asas Kelayakan atau Kegunaan (Expediency Principle)}

Yaitu asas yang menghendaki bahwa dalam beroprasinya sistem peradilan pidana menyeimbangkan antara hasil yang diharapkan dengan biaya-biaya yang dikeluarkan. Bekerjanya sistem peradilan pidana dimulai dengan memperhitungkan bahwa apakah yang dilakukan itu sebuah aktivitas yang layak 79 Lihat, Rusli Muhammad, Sistem Peradilan Pidana...Op.Cit. hlm. 10-13. 32 dan berguna untuk dilakukan sehingga terkesan lebih memberikan kemanfaatan ketimbang kerugian.

\section{Asas Prioritas (Priority Principle)}

Yaitu asas yang menghendaki sistem peradilan pidana mempertimbangkan aktivitas-aktivitas yang perlu didahulukan, misalnya menyelesaikan perkaraperkara yang dinilai membahayakan masyarakat atau yang menjadi kebutuhan yang mendesak. Asas ini didasarkan pada semakin beratnya sistem peradilan pidana, sementara kondisi kejahatan cenderung semakin meninggi. Prioritas disini tidak hanya berkaitan dengan pelbagai kategori tindak pidana, tetapi bisa juga pelbagai tindak pidana dalam kategori yang sama dan juga berkaitan dengan pemilihan jenisjenis pidana atau tindakan yang dapat diterapkan kepada pelaku. 


\section{Asas Proporsionalitas (Proporsionality Principle)}

Yaitu asas yang menghendaki agar sistem peradilan pidana dalam penegakan hukum pidana hendaknya mendasarkan pada proporsional antara kepentingan masyarakat, kepentingan negara, dan kepentingan pelaku tindak pidana dan kepantingan korban. Dengan asas ini maka sistem peradilan pidana bukan sekedar menjalankan dan melaksanakan hukum melainkan seberapa jauh penerapan hukum cukup beralasan dan memenuhi sasaran-sasaran yang dinginkan.

\section{Asas Subsidair (Subsidairity Principle)}

Yaitu asas yang menerangkan bahwa penerapan hukum pidana yang utama dalam menanggulangi kejahatan tapi sanksi hanya merupakan alternatif kedua. Dengan asas ini berarti sistem peradilan pidana dapat berbuat menerapkan hukum 33 pidana jika hal itu sudah tidak ada pilihan lain, namun jika masih ada sarana lainnya yang dapat digunakan menanggulangi kejahatan maka sarana hukum pidana sedapat mungkin dihindari.

\section{Asas Kesamaan di Depan Hukum (Equality Before The Law)}

Yaitu asas yang menerapkan bahwa setiap orang harus diperlakukan sama dimuka hukum, tidak ada pilih kasih semuanya mendapat perlakuan dan hak yang sama. Dengan asas ini sistem peradilan pidana selalu mengedepankan kesamaan sehingga siapapun dan bagaimanapun kondisi setiap subyek hukum yang menghendaki pelayanan dalam penyelesaian permasalahan hukum harus dipandang sama dengan perlakuan yang sama pula, harus menghindari diskriminatif dengan 
tidak mendahulukan dan mengutamakan yang berekonomi atau yang berkuasa sementara mengabaikan atau meninggalkan yang tidak atau kurang mampu.

Pembahasan mengenai Sistem Peradilan Pidana terasa ada yang kurang jika tidak memaparkan hukum acara pidana (hukum formil publik), sebab beberapa komponen (sub-sistem) dalam SPP di Indonesia sedikit-banyak memiliki korelasi dengan KUHAP. maka dianggap perlu pula untuk memaparkan asas-asas hukum acara pidana, sebelum masuk pada asas-asas yang biasa kita ketahui. Dua macam asas yang jarang dibahas, yaitu Pertama, asas akusator (Accusatoir) yaitu asas yang menekankan bahwa setiap tersangka/terdakwa memiliki hak untuk tidak dijadikan obyek persidangan, melainkan bahwa tersangka/terdakwa dapat memberikan keterangan sesuai hati nurani dan beralibi sesuka hati, meskipun 34 demikian tugas aparat penegak hukum untuk menggali kebenaran yang hakiki dari sebuah peristiwa hukum. Asas akusator lawan dari asas inkuisator (Inquisitoir), maksud dari asas inkuisator ini adalah tersangka/terdakwa menjadi obyek dalam persidangan, dan pengakuan maupun keterangan tersangka/terdakwa merupakan bukti yang paling kuat.

Kedua, yaitu asas Oportunitas, yang bermakna sebagai asas hukum yang memberikan wewenang kepada penuntut umum untuk menuntut atau tidak menuntut dengan atau tanpa syarat seseorang atau korporasi yang telah mewujudkan delik demi kepentingan umum. Dimasa pra-kemerdekaan, asas oportunitas ini belum diberlakukan secara tertulis, melainkan hanya dijalankan sesuai dengan kebiasaan 
Jaksa Penunut Umum (JPU) dalam melaksanakan tuntutan kepada tersangka/terdakwa suatu perkara pidana.

Asas-asas Sistem Peradilan Pidana yang ada di Indonesia berdasarkan Undang-Undang Nomor 8 tahun 1981 :

1. Perlakuan yang sama dimuka umum, tanpa diskriminasi apapun. Dalam pasal 5 ayat (1) Undang-Undang Nomor 14 tahun 1970 dengan tegas menyebutkan bahwa Pengadilan mengadili menurut hukum dengan tidak membedakan orang. Ini berarti bahwa di depan pengadilan mereka (yang disangka, ditangkap, ditahan, dituntut dan dihadapkan ke muka pengadilan) harus diperlakukan sama tidak ada pembedaan perlakuan terhadap siapapun juga baik itu parbedaan warna kulit, agama/keyakinan, kaya atau miskin, dll namun realitas memperlihatkan hal yang berbeda akan hal ini.

2. Asas praduga tidak bersalah (presumption of innocence). Disini berarti bahwa setiap orang yang disangka, ditangkap, ditahan, dituntut dan dihadapkan ke muka pengadilan wajib untuk dianggap tidak bersalah hingga ada keputusan dari pengadilan yang menyatakan kesalahannya dan memperoleh kekuatan hukum yang tetap (penjelasan umum butir 3c KUHAP). Asas ini juga diatur dalam Undang-Undang Nomor 14 tahun 1970 tentang Pokok Kekuasaan Kehakiman (yang sekarang terdapat dalam pasal 8 Undang-Undang Nomor 4 tahun 2004 tentang Kekuasaan Kehakiman). 
3. Hak untuk memperoleh kompensasi (ganti rugi) dan rehabilitasi. Sebagai tuntutan ganti rugi disini diatur dalam pasal 95 KUHAP, dan mengenai tuntutan rehabilitasi diatur dalam pasal 97 KUHAP.

4. Hak memperoleh bantuan hukum. Dalam hal ini untuk memenuhi kepentingan pembelaan diri atas tindakan pidana yang disangkakan, terdakwa diberikan hak untuk memperoleh bantuan hukum. Namun dari beberapa faktor yang ada pada saat ini menjadi penghambat terhadap pelaksanaan bantuan hukum yang merata. Dan yang terlihat pada beberapa kasus, kehadiran seorang pengacara/advokat sebagai mitra dari tersangka, realitas menunjukan bahwa pengacara justru dianggap mempersulit pemeriksaan suatu perkara oleh aparat penegak hukum. Padahal adanya pengacara adalah untuk membantu aparat penegak hukum dalam mencari dan menemukan kebenaran materiil.

5. Hak kehadiran terdakwa di muka pengadilan. Dalam asas ini menuntut keberadaan terdakwa pada proses peradilan hingga putusan pengadilan dibacakan, dan tidak boleh diwakili oleh siapapun. Terkecuali pada tindak pidana korupsi, pencucian uang dan pemeriksaan cepat.

6. Peradilan yang bebas ini dilakukan dengan cara cepat dan sederhana. Asas peradilan bebas ini melingkupi asas lainnya selain cepat, sederhana. Yakni: biaya ringan serta bebas, jujur, tidak memihak. Maksudnya adalah tidak 
berbelit-belit, acaranya yang jelas, mudah dimengerti, biaya ringan yang dapat dipikul oleh rakyat

7. Peradilan yang terbuka untuk umum. Disini masyarakat termasuk pers dapat hadir, menyaksikan dan meliput jalannya persidangan. Dan apabila proses peradilan dalam pengadilan dari awal sampai akhir itu tertutup untuk umum, maka putusan yang ditetapkan oleh Hakim menjadi tidak sah. Keputusan Hakim dapat menjadi sah dalam proses persidangan tertutup apabila dalam pembacaan putusan perkaranya terbuka untuk umum. Penetapan Hakim mengenai persidangan tertutup untuk umum tidak dapat dibanding, meskipun putusan perkaranya dibacakan dalam sidang yang terbuka untuk umum. Pertimbangan menetapkan suatu sidang dinyatakan tertutup seluruhnya atau sebagian untuk umum diserahkan sepenuhnya kepada Hakim sesuai dengan KUHAP.

8. Pelanggaran atas hak-hak warga negara (penangkapan, penahanan, penggeledahan, dan penyitaan) harus berdasarkan pada Undang-undang dan dilakukan dengan surat perintah (tertulis). Asas legalitas dalam hukum pidana berarti bahwa segala tindakan kepolisian yang mempergunakan upaya paksa (penangkapan, penahanan, penggeledahan, penyitaan dan tindakan lainnya) harus berdasarkan perintah tertulis oleh pejabat yang diberi wewenang oleh Undang-undang dalam hal serta dengan cara menurut Undang-undang. Asas legalitas dalam hukum pidana ini berbeda dengan asas legalitas dalam hukum pidana materiil 
(pasal 1 ayat (1) KUHP, yakni Nullum delictum nulla poena sine previa lege poenali)

9. Hak seorang tersangka untuk diberi tahu tentang persangkaan dan pendakwaan terhadapnya. Asas ini disebut dalam angka 3 huruf g penjelasan umum KUHAP.

10. Kewajiban pengadilan untuk mengendalikan pelaksanaan putusannya. Disini tugas hakim pengawas dan pengamat inilah untuk mengetahui sampai dimana putusan pengadilan itu terlihat hasil baik buruknya pada diri terpidana masing-masing. Dan hakim tersebut harus ikut serta dalam mempertimbangkan apakah seorang terpidana dapat diberikan pelepasan bersyarat. Kedua tugas ini bertujuan untuk lebih mendekatkan pengadilan dengan lembaga pemasyarakatan dan menetapkan pemasyarakatan terpidana dalam rangka proses peradilan pidana 


\section{PENUTUP}

Asas-asas hukum Peradilan Tata Usaha Negara yang menjadi karakteristik hukum acara Peradilan Tata Usaha Negara di antaranya sebagai berikut: Asas praduga rechtmatig (vermoden van rechtmatigheid, praesumtio iustae causa) Asas praduga rechtmatig adalah gugatan tidak menunda atau menghalagi dilaksanakannya keputusan badan atau pejabat Tata Usaha Negara yang digugat (pasal 67 ayat (1) Undangundang no 5 tahun 1986; Asas pembuktian bebas, Hakim yang menetapkan beban pembuktian. Hal ini berbeda dengan ketentuan 1865 BW. Asas ini dianut oleh pasal 101 UU No 5 tahun 1986, hanya saja masih dibatasi ketentuan pasal 100. Asas keaktifan Hakim (dominus Litis). Keaktifan kekuatan mengikat kedudukan para pihak karena tergugat adalah pejabat Tata Usaha Negara sedangkan penggugat adalah orang atau badan hukum perdata. Penerapan asas ini antara lain terdapat dalam ketentuan pasal 58,63 ayat (1) dan (2), pasal 80 dan pasal 85. Asas putusan Peradilan memiliki kekutan mengikat "erga omnes “. Sengketa TUN adalah sengketa hukum public. Dengan demikian putusan pengadilan berlaku bagi siapa saja, tidak hanya bagi para pihak yang bersangkutan. Dalam rangka ini kiranya ketentuan pasal 83 tentang intervensi bertentangan dengan asas erga omnes.

Asas-asas umum pemerintahan yang baik sebagai berikut: Asas kepastian hukum (principle of legal security); Asas keseimbangan (principle of proportionality); Asas kesamaan dalam mengambil keputusan (principle of equality); Asas bertindak cermat (principle of carffulness); Asas motivasi untuk setiap keputusan (principle of motivation); Asas tidak mencampuradukan kewenangan (principle of competence); 
Asas permainan yang layak (principle of fair play); Asas keadilan dan kewajaran (principle of reasonable or prohibition of arbitrariness); Asas kepercayaan dan menanggapi pengharapan yang wajar (principle of meeting raised expectation); Asas meniadakan akibat suatu keputusan yang batal (principle of undoing the concequences of an annulled decision); Asas perlindungan atas pandangan atau cara hidup pribadi (principle of protecting the personal may of life); Asas kebijaksanaan (sapientia); Asas penyelenggaraan kepentingan umum (principle of public service).

Asas-asas yang menjadi landasan dalam mekanisme atau bekerjanya sistem peradilan pidana adalah sebagai berikut : Asas Legalitas (Legality Principle), Asas Kelayakan atau Kegunaan (Expediency Principle), Asas Prioritas (Priority Principle), Asas Proporsionalitas (Proporsionality Principle), Asas Subsidair (Subsidairity Principle), Asas Kesamaan di Depan Hukum (Equality Before The Law) 


\section{DAFTAR PUSTAKA}

Darmini Roza dan Laurensius Arliman S Peran Pemerintah Daerah Di Dalam Melindungi Hak Anak Di Indonesia, Masalah-Masalah Hukum, Volume 47, Nomor 1, 2018.

Laurensius Arliman S, Komnas HAM dan Perlindungan Anak Pelaku Tindak Pidana, Deepublish, Yogyakarta, 2015.

Laurensius Arliman S, Penguatan Perlindungan Anak Dari Tindakan Human Trafficking Di Daerah Perbatasan Indonesia, Jurnal Selat, Volume 4, Nomor $1,2016$.

Laurensius Arliman S, Problematika Dan Solusi Pemenuhan Perlindungan Hak Anak Sebagai Tersangka Tindak Pidana Di Satlantas Polresta Pariaman, Justicia Islamica, Volume 13, Nomor 2, 2016.

Laurensius Arliman S, Pelaksanaan Perlindungan Anak Yang Tereksploitasi Secara Ekonomi Oleh Pemerintah Kota Padang, Veritas et Justitia, Volume 2, Nomor 1, 2016.

Laurensius Arliman S, Kedudukan Ketetapan MPR Dalam Hierarki Peraturan Perundang-Undangan Di Indonesia, Lex Jurnalica, Volume 13, Nomor 3, 2016.

Laurensius Arliman S, Komnas Perempuan Sebagai State Auxialiary Bodies Dalam Penegakan Ham Perempuan Indonesia, Justicia Islamica, Volume 14, Nomor 2, 2017.

Laurensius Arliman S, Peranan Pers Untuk Mewujudkan Perlindungan Anak Berkelanjutan Di Indonesia, Jurnal Ilmu Hukum Tambun Bungai, Volume 2, Nomor 2, 2017.

Laurensius Arliman S, Mewujudkan Penegakan Hukum Yang Baik Untuk Mewujudkan Indonesia Sebagai Negara Hukum, Jurnal Hukum Doctrinal, Volume 2, Nomor 2, 2017.

Laurensius Arliman S, Participation Non-Governmental Organization In Protecting Child Rights In The Area Of Social Conflict, The 1st Ushuluddin and Islamic Thought International Conference (Usicon), Volume 1, 2017. 
Laurensius Arliman S, Partisipasi Masyarakat Dalam Pembentukan Perundang-Undangan Untuk Mewujudkan Negara Kesejahteraan Indonesia, Jurnal Politik Pemerintahan Dharma Praja, Volume 10, Nomor 1, 2017, https://doi.org/10.33701/jppdp.v10i1.379.

Laurensius Arliman S, Peran Komisi Perlindungan Anak Indonesia Untuk Mewujudkan Perlindungan Anak, Jurnal Respublica Volume 17, Nomor 2, 2018.

Laurensius Arliman S, Menjerat Pelaku Penyuruh Pengrusakan Barang Milik Orang Lain Dengan Mempertimbangkan Asas Fungsi Sosial, Jurnal Gagasan Hukum, Volume 1, Nomor 1, 2019.

Laurensius Arliman S, Ilmu Perundang-Undangan Yang Baik Untuk Negara Indonesia, Deepublish, Yogyakarta, 2019.

Laurensius Arliman S, Isdal Veri, Gustiwarni, Elfitrayenti, Ade Sakurawati, Yasri, Pengaruh Karakteristik Individu, Perlindungan Hak Perempuan Terhadap Kualitas Pelayanan Komnas Perempuan Dengan Kompetensi Sumber Daya Manusia Sebagai Variabel Mediasi, Jurnal Menara Ekonomi: Penelitian dan Kajian Ilmiah Bidang Ekonomi, Volume 6, Nomor 2, 2020.

Laurensius Arliman S, Pendidikan Kewarganegaraan, Deepublish, Yogyakarta, 2020.

Laurensius Arliman S, Makna Keuangan Negara Dalam Pasal Pasal 23 E UndangUndang Dasar 1945, Jurnal Lex Librum, Volume 6, Nomor 2 Juni 2020, http://dx.doi.org/10.46839/1ljih.v6i2.151.

Laurensius Arliman S, Kedudukan Lembaga Negara Independen Di Indonesia Untuk Mencapai Tujuan Negara Hukum, Kertha Semaya Journal Ilmu Hukum, Volume 8, Nomor 7, 2020.

Laurensius Arliman S, Pelaksanaan Assesment Oleh Polres Kepulauan Mentawai Sebagai Bentuk Pelaksanaan Rehabilitasi Bagi Pecandu Dan Korban Penyalahgunaan Narkotika, Jurnal Muhakkamah, Volume 5, Nomor 1, 2020.

Laurensius Arliman S, Aswandi Aswandi, Firgi Nurdiansyah, Laxmy Defilah, Nova Sari Yudistia, Ni Putu Eka, Viona Putri, Zakia Zakia, Ernita Arief, Prinsip, Mekanisme Dan Bentuk Pelayanan Informasi Kepada Publik Oleh Direktorat Jenderal Pajak, Volume 17, No Nomor, 2020. 
Larensius Arliman S, Koordinasi PT. Pegadaian (Persero) Dengan Direktorat Reserse Narkoba Polda Sumbar Dalam Penimbangan Barang Bukti Penyalahgunaan Narkotika, UIR Law Review, Volume 4, Nomor 2, 2020, https://doi.org/10.25299/uirlrev.2020.vol4(1).3779.

Laurensius Arliman S, Tantangan Pendidikan Kewarganegaraan Pada Revolusi 4.0, Ensiklopedia Sosial Review, Volume 2, Nomor 3, 2020.

Muhammad Afif dan Laurensius Arliman S, Protection Of Children's Rights Of The Islamic And Constitutional Law Perspective Of The Republic Of Indonesia, Proceeding: Internasional Conference On Humanity, Law And Sharia (Ichlash), Volume 1, Nomor 2, 2020.

Otong Rosadi danLaurensius Arliman S, Urgensi Pengaturan Badan Pembinaan Idelogi Pancasila Berdasarkan Undang-Undang Sebagai State Auxiliary Bodies yang Merawat Pancasila dalam Perspektif Hak Asasi Manusia, Prosiding Konferensi Nasional Hak Asasi Manusia, Kebudayaan dan Tujuan Pembangunan Berkelanjutan Indonesia pada Masa Pandemi Covid-19: Tantangan untuk Keilmuan Hukum dan Sosial Volume 1, Universitas Pancasila, Jakarta, 2020. 